\title{
Like Day and Night: On Becoming a Teacher in Two Distinct Professional Cultures in Rural Saskatchewan
}

\author{
Dianne M. Miller
}

\author{
Laurie-Ann M. Hellsten \\ University of Saskatchewan
}

Framed within ecological and institutional ethnography perspectives, and situated within a larger study of beginning teachers in the Canadian province of Saskatchewan, this paper focuses on the dramatically different experiences of one beginning teacher who happened to secure half-time contracts in two rural schools within commuting distance of one another. His account of these experiences and how he makes sense of them orient researchers to the broad social, economic, and material conditions that organize the mutually dependent work of parents and teachers. This analysis contributes to beginning teacher research by affirming the value of personal stories of learning to teach, moving beyond studies of individual adaptation to fixed notions of professional success, and opening to scrutiny the shared conditions of early and later career teachers as they are institutionally and discursively organized, thus promoting appreciation of the complexities of learning to teach attuned to variation in local rural circumstances.

Keywords: beginning teachers, rural education, institutional ethnography, professional enculturation

This paper focuses on David [pseudonym], a first-year teacher in rural Saskatchewan, whose luck in getting part-time contracts in two dramatically different schools raises new questions for scholars concerned about the experiences of beginning teachers, professional school cultures, and the relationship between school and community in rural contexts. With part-time contracts in two rural communities in his first year, the differences in his teaching experiences seem to have to do with socioeconomic circumstances, impending school closures, administrative leadership, and relationships with parents more so than with rurality. Nonetheless, his teaching story offers riveting glimpses into diverse teaching and learning worlds located only a few miles apart. As researchers, we are reminded of the particularities of rural experience which eschew generalization, and become attentive to the larger social relations that organize the work of teachers.

In focusing on a single beginning teacher's story, we are guided by the theoretical work of sociologist Dorothy Smith (1987), who considers the "everyday world as problematic" (title). Her pioneering institutional ethnographies take up individual experience as a "point d'appui," or point of entry into understanding how an experience is embedded in the extended social relations that both constitute and organize it (p. 159; see also Griffith \& Smith, 2005).

Her approach relates the local and particular to the generalized and abstract relations that are often invisible determinants of an individual's experience. While we are not producing an institutional ethnography, we are alert to the ways David's experiences in the two schools are organized by relations and discourses outside of them. As well, following Costigan (2014), we draw on the notion of the ecological as a conceptual framework; that is, we see the "process of teaching as an emotionallycharged, and politicized decision that is negotiated through autobiographical, educational, social, and ideological ecologies or landscapes” (p. 6). In other words, David's story offers revealing indications of the wider world or "unique habitat" of teaching (p. 3).

We draw on data from a two-year crosssectional study on the early career paths of beginning teachers in the Canadian province of Saskatchewan undertaken by a research team from one of the province's teacher education programs in conjunction with the teachers' federation. Through analysis of data collected by survey and case study, the overall goal of the study is to track employment patterns among new teachers including retention rates; to develop a sense of the work-related activities of new 
teachers and the relationships that affect their early careers; and to develop an understanding of how they are socialized or enculturated into the profession, including their perceptions about the supports and resources necessary to facilitate this critical transition. The study is prompted by concerns rife in Canada and the United States with regard to high attrition rates in teaching, especially amongst new teachers. These rates vary depending on the source, how measured, and the locale, but some estimates in the United States indicate close to $50 \%$ of new teachers are no longer in the profession after five years of teaching (Okhremtchouk et al., 2015, p. 332; Gourneau, 2014, pp. 299-300; for an international review, see MacDonald, 1999). Moreover, those who give up without finding a job in teaching are generally not tracked. Concerns about the economic and social costs of teacher attrition have stimulated varied research into the work lives of early career teachers and professional induction practices. A ProQuest Education database search using the terms "beginning teachers" and "retention" or "induction" yielded 1500 results in scholarly journals since 1994 when research in this area began to accelerate.

In addition to a comprehensive survey of beginning teachers who graduated from the same university over a two-year period, twelve in-depth interviews were conducted using maximum variation sampling to provide insight into a diverse range of experiences: male, female; urban, rural; elementary, secondary; northern and band-operated schools. ${ }^{16}$ Analysis of these interviews following the guidelines offered by Braun and Clark (2006) and Boyatzis (1998) reveals themes which are corroborated in the literature reviewed by Fantilli \& McDougall (2009); i.e., challenges include students' diverse needs and behavior, heavy workloads and time management, relationship with parents, insufficient resources, and maintaining "personal sanity" in what are often isolating and difficult circumstances (p. 815). These concerns are not all that different from the "negative workplace stressors" revealed in a local Saskatchewan study that included new and veteran urban teachers, indicating that the challenges associated with the complex work of teachers are not just issues for those at the start of their careers (Martin, Dolmage, \& Sharpe, 2012, 18-20).

\footnotetext{
16 Bands are a structure of governance for First Nation peoples regulated by the federal Indian Act; band-operated schools on reserves are funded federally through Band Councils or First
}

Beginning teachers in rural Saskatchewan identify additional challenges related to acceptance in a community, understanding the community, social isolation, overlap between their personal and professional lives, as well as fewer resources and a heavier workload related to their geographic location (Hellsten, McIntyre, \& Prytula, 2012, p. 13). Competition for full-time permanent teaching positions is fierce in those areas of Saskatchewan deemed most desirable because of location in or proximity to an urban center. Beginning teachers speak of finding positions because of the demand for their particular subject area (e.g., French language) or because connections fostered through either their internship or relationships netted them an interview (backdoor). Several have begun with temporary contracts and relay the mantra that they will say "yes, yes, yes" to everything until a permanent contract is attained. Many participants comment on the hectic pace of their schedules and how teaching and related activities (coaching, planning, extra-curricular) absorbs all of their time (“24/7”). Several take no time for coffee breaks and eat their lunches on the go. Many are critical of formal mentorship programsthey are "full of crap" "don't work," or are likened to surveillance mechanisms—-but all have sought and valued support from other teachers and/or from their own families. Administrative support or the lack of it looms large in their stories and appears to be a critical variable in their outlook and sense of hope. And while they do not necessarily imagine themselves teaching their whole lives, they talk about teaching in the language of the heart (Draper, 2000; Gruwell, 2007; Intrator, 2002; Palmer, 2007)—being there, in front of the class, in the gym, working with kids, 'getting it', helping them 'get it', giving backall talk about teaching as engaging vital aspects of their being and calling forth a larger self that transcends the mundane aspects of their jobs. Their language resonates with the positive aspects of teaching reported by Martin, Dolmage, \&Sharpe (2012, pp. 20-21).

Given the nature of employment availability in Saskatchewan, some new teachers like David secure part-time teaching contracts in more than one school. Like him, they may find themselves teaching in two schools with very different demographics and

Nation Education organizations (at a reduced rate in comparison to provincial schools) and administered by the band. See "First Nation Elementary and Secondary Schools," n.d.; Angus, 2015). 
professional cultures. Much of the literature on early career teachers focuses on how they integrate into the prevailing school culture more so than on investigations of the dynamics of that culture and its receptivity to new teachers. While schools function at various points on a spectrum of "effectiveness" and "school improvement" (see Creemers \& Reezigt, 1997; Renihan \& Renihan, 1989; Renihan \& Renihan, 1991; Hajnal, Walker, \& Sackney, 1998; Trujillo, 2013), study of the beginning teacher's individual struggles and successful (or not) adaptation often takes precedence over analysis of the institutional milieu and the material conditions of teaching that shape a beginning teacher's experience (see, for example, Gourneau, 2014; Hebert \& Worthy, 2001; Okhremtchouk et al., 2015; Romano \& Gibson, 2006; Zepeda \& Ponticell, 1997) ; Van Zandt Allen, 2013). When immersed like David in two distinct rural school cultures, the institutional context is brought into sharp relief. How does he make sense of these diverse school settings and their different expectations and demands on his expertise and resources? How does he explain these differences? And what might we who educate and work with beginning teachers in rural contexts learn from his story?

\section{Provincial Context}

Saskatchewan is a sparsely populated midwestern province $\left(651,900 \mathrm{~km}^{2}\right)$ bordered by Manitoba to the east, Alberta to the west, the Northwest Territory to the north, and Montana and North Dakota to the south. About forty per cent of the entire population (1.13 million) is distributed between the two major cities, Regina, the capital, and Saskatoon, the larger urban center (Statistics Canada, 2011). Agriculture and resource extraction (oil and gas, potash, uranium, timber) are the major economic drivers (Statistics Canada, 2015). Globalization has steered agriculture away from the locally-owned family farm towards corporate farming, a trend which accelerated in the 1990s (Wittman, Desmerais, \& Wiebe, 2011). As is the case for much of Canada and the US, the rural settler population is dwindling as young people migrate to the cities or other areas of increased employment opportunities (Ares Abalde, 2014; Bollman \& Clemenson, 2007; Tremblay, 2001; Smith 2002). Rural schools which historically emphasized preparation for rural life now groom students for mobility. Sociologist Michael Corbett
(2007) names this phenomenon in rural education as "learning to leave" (pp. 1-6).

In the early 2000s, longstanding concerns about equity and efficiencies in funding and education services in Saskatchewan ignited the political will to mandate what many considered a long overdue major re-structuring of school divisions. From 2004-2006, there was a reduction from 81 to 28 school divisions (Kirk, 2008). A two-year moratorium on school closures during the re-structuring period ended with announcements of several closures attributed to declining enrollments because of lower birth rates and migration to urban areas (Oncescu \& Giles, 2014, p. 296; “Sask school divisions,” 2007). Since 2008, while Saskatchewan has experienced steady population growth, it is unevenly distributed throughout the province. The specter of school closure still looms large in rural school divisions distant from urban centers.

\section{David's Day and Night}

David, a participant in the 25-34 age group who graduated from the province's largest university as an elementary teacher, is one whose plan to become a teacher, like many in his cohort, took time to come to fruition. His was not a straight path, nor did he set out with surety:

When I came out of high school, I tutored math quite heavily and really got the idea of getting someone to learn something was a lot of fun and stuff. Went to university for awhile thinking I'd get my math degree and then teach high school math and then got into my second semester of math and went, yeah, I don't want to do this anymore. So I left university for quite awhile and started working at a golf store and part of the golf store was teaching golf lessons but after about six years of being there, I really started to look into the mirror and said 'is this what I want to do for the rest of my life?' Well my wife said, "What do you enjoy the most?" and I said I love the golf lessons. I said there just was no doubt about it; it's my favourite part of the job. And she said, "Well how do you make that work in real life?” And I went, I don't know. You know, there's just two choices - being a golf pro which is actually maybe even a harder life than a retail golf person or going back to what I originally thought I wanted to do which was teaching. So, you know I kind of went back to university and 
started taking the classes to do it and then, you know, still kind of unsure until....[in a kinesiology class] we got to go into a school to teach and part of it was a practicum, you know, go, go, go. From the moment I hit that gym and was teaching, it was like there's just no doubt that's where I wanted to be.

Once he graduated, David secured full-time work with replacement contracts at two schools. He acknowledges that acquiring full-time work the first year is unusual in these tight times, and attributes his success to his "backdoor channels"-- that he had made a good impression as an intern in one of the schools that subsequently hired him, that he taught one of the superintendents in a sports context, and that he was known in the system through his wife, also a teacher, who has, in his words, more of a "normal look for a teacher who just graduated"; that is, a history of substitute teaching and temporary contracts. David teaches the same grades and subject (not his teaching area) in both schools on alternate days. He appreciates that his planning time is virtually cut in half and that he can correct mistakes or make adjustments as he teaches the same material a second time. He regrets not teaching his primary subject, Phys. Ed, and has gladly taken on coaching team sports as compensation, but anticipates that these extra-curricular activities will not combine well with his new responsibilities as a father:

Because I mean, I got through with the bulk of the first year, kind of having my own time to do things. And now my time isn't my time anymore. Yeah, that would be one thing. That idea of, well okay now I'm a dad, you know, I don't want to spend weekends at tournaments.

While David teaches the exact same grades and subjects, his experience is dramatically different in the two schools. Both are rural schools within 20-25 minutes of an urban centre. The K-8 school is located in "the middle of a field" in a relatively affluent community of "big farms" and has over a dozen teachers for about ninety-five students; the other school (Grades 5-8 with 3.5 teaching positions) is in an economically depressed town of 200, where "you are seeing the downside of small-town Saskatchewan.”

The latter school is viewed as having a high percentage of students with special needs who have not been diagnosed and thus do not receive additional support with teaching or educational assistants.
Behavioral issues in the school are also seen to be on the rise as the decision date regarding school closure nears. In David's estimation, the community's displeasure with the anticipated school closure heightens tensions with its teachers:

“... right now parents in that school are not loving us and ... you know, everything that goes around that and I think...I don't know if I quite expected that. That kind of an issue, it's dealing with parents."

Relationships with parents figure strongly in

David's comparison of the two schools. The parent council of the smaller 5-8 school is described as “dysfunctional," while the "highly effective" parent council of the other school had raised several thousand dollars to enhance classroom learning through technological innovation.

"Effective" is the word most often used in David's description of the K-8 school: "Look up how what an effective school is supposed to be and there's your model for it." In elaborating the characteristics of this particular effective school, David speaks of striving for excellence, high expectations, teacherinitiated innovations, pushing the boundaries, community support, and strong administrative leadership. He refers to teachers sitting around a table in the staffroom discussing new teaching methods. He gives an example of a teacher developing a student-led parent interview as a successful and carefully planned innovation. He stresses parental support of teacher initiatives and how any problems are "alleviated fairly easily" with a talk to the principal.

By contrast, in the 5-8 school which is understaffed by comparison, the teachers are most often described as stretched thin, tired, worn out, and dragged down. For David there is a different energy to his work in the two schools. Whereas in the K-8 he is always "pushing the boundaries," in the 5-8 school, "it's more about just getting the day done." A sense of being under siege permeates his description of teachers always having to justify everything they do to every parent and this feeling is apparently reflected in the wider community: “...the motto of the town is let's just get through till the end of the year, because we don't really want to take the parents on anymore.” With such a small staff, there is little opportunity for group discussion or planning or even quiet self-reflection about how things might be done differently:

I think a lot of it just absolutely just has to do with teachers being spread too thin. It really is. 
You know, you go home at the end of day, you're exhausted. Haven't had time to sit down and rest at all through the day.

Interestingly, the norms and expectations of each school are not communicated directly but are quickly internalized and made manifest in the teachers' practices. David reflects on his different work behavior in each school:

...You know every teacher is there [K-8 school]

by $8: 15$ in the morning. The other school, as

long as you're there by 8:35am when the kids roll off the bus. The K-8 school, no teacher leaves the parking lot until $4 \mathrm{pm}$. The other school, there is a teacher there that is chasing the bus basically and by that I mean, you know, the buses leave at 3:05pm, she's out of school at $3: 10 \mathrm{pm}$. So I mean, where that came from again, I don't know, and I really don't. I mean, other than, you know, if you look at the one school [K-8]... the teacher leaders, you know the ones that ... everybody looks to in the school, do that. So whether it was just something that was kind of handed down from them over the years or you know, a principal at some point said you guys can't leave until that time, I'm not sure. But I do know that... if you look at the one school, I get there at 8:00am every morning, the other school...I get there at 8:15am.

David's particular situation brings to light a fascinating instance of professional enculturation. His reading of the two school environments produces a differential set of norms, values, and expectations and he adjusts his attitude and behavior accordingly. He works to make sense of these differences within the parameters of the discourses readily available to him and the very limited time to spend in reflection, study, and dialogue. He feels unprepared "to deal" with parents, particularly those who are in opposition to the division's plan. He is aware of the socioeconomic differences in the two communities and some of the ways that these are manifested (more and better resources in the more affluent K-8 school; kids with little or no lunch and/or kids who are less school ready and compliant in the poorer school). He draws on particular courses in his preservice education to describe his understanding of the culture of the schools and relates school effectiveness in part to strong administrative leadership.

His articulate reflections on his work lead the research team to reflect on our own work as teacher educators and professional support providers. One reason our interest is especially piqued is that these two diverse work experiences reveal the complex nexus of relations amongst school, community, parents, and the economy that we work to theorize. For example, how are parents positioned with respect to their children's education: are they perceived as 'partners', 'allies' 'objects' or 'obstacles' in the process? Do educator practices confirm or belie the stated intent with regard to parents? With whom does power reside and how is it brokered? While parental involvement is espoused in most current forms of schooling and especially so in those which come under the rubric of community education, researchers such Amendt (2008) and Pushor (2007a and 2007b) ask who is setting and carrying out the agenda. What does it mean to share real power with parents? And how do educators engage authentically with parents who are marginalized by the wider society and who may feel fear, anger, and distrust as a legacy of their own school experiences?

Much of David's description of his work experiences in the two communities revolves around relationships with parents. In the more affluent school (K-8), he has few problems with parents and these relate more to extra-curricular than classroom issues:

Actually, probably my biggest problem with parents comes more around extra-curricular activities than it does around the actual teaching in school. You know, well you're being too competitive, you're not being competitive enough. You know it kind of falls into there. In the poorer community, relations with parents are strained. Teachers are focused on getting through the day and the year. It is difficult for David to judge how much the possible school closure is responsible for this negativity although this presents itself as ready-made and readily subscribed to explanation: ...mom and dad aren't real happy right now with the school board and it's really filtering into the kids...You know, the kids definitely are getting harder and harder to kind of settle down and stuff. I mean, you know, I'm a new teacher there, but talking to the other teachers--it's just-there's a definite change.

Issues of irresponsibility and lack of respect for one another are noted in this school (5-8). Several students are suspected to have ADHD. There are no special needs supports in place. 
I'm not sure what's happening. Whether it's mom and dad not following through on the signing of the papers or if it's [Ministry of Ed] changing of what is high cost now and stuff. You know we have a lot of behavioral problems in that one school [5-8] whereas the other one [K-8] I don't have that.

Interestingly, there are limited extra-curricular activities in this school because there are fewer staff, but this does not seem to be taken up as a contributing factor to the students' negative behavior: I mean, in my one school [K-8], there's just not even a doubt that we, you know, enter every sport. I mean, girls and boys get into all the teams, we have extra clubs, eco kits, and things like that. And then at this other school [5-8] where we're 3.5 staff and we're responsible still for all the, you know, EA [Educational Assistance] or STF [Saskatchewan Teacher Association] reps and all that type of things that go along with it, you know, for the extracurricular stuff, there's not a lot of time left for the teacher to do this stuff.

"Across the board" he finds the hardest situations with parents to be ones where they take the child's side, dismissing the teacher's concern: "And you know mom and dad have to be their child's biggest advocate but at times they just don't understand that, you know, we are not lying to them. We are not here intentionally to hurt their child.”

While David uses the gender-neutral term "parents," and sprinkles his talk with "mom and dad," when asked he notes that "very rarely is dad the leader of anything. You know dealing with school stuff, it's the wife 99 out of a 100 times you're dealing with.” His main contact with parents is with mothers who do not work outside the home:

Very rarely do I get into it with the dad or really have any discussions. I have to think actually. No, never once did I have a problem with the dad...the [moms] that aren't working are probably the ones that, you know, everything kind of revolves around the kid. So, I mean they're always trying to know what's going on, what's happening in school.

Since the interview with David, the 5-8 school has closed and researchers have lost the opportunity to investigate further the dynamics of this particular community as they play out in the work lives of beginning teachers in rural settings. Yet this glimpse into one beginning teacher's experience in two very different schools raises important questions and speculations that turn our gaze to the broader social and material conditions that organize teachers' work.

\section{Discussion}

The syntactical pairing of 'to deal with' and 'parents' occurs a lot in everyday talk among teachers and teacher candidates. What can we learn by examining the language we use to describe these relationships? To 'deal with' something connotes taking measures with respect to a problem or person to rectify a situation. Teachers' interaction with parents is 'dealing with'. The agent is the teacher; the object of the action is the parent (usually the mother). Parents are positioned outside the sphere of day-to-day action in schools and their entries into that sphere are treated as intrusions, their questions as demands for justification. Teacher authority is called into question and teachers feel besieged. Yet in contexts where there is 'community support,' teachers feel valued, appreciated, and encouraged to 'give back' to the community. Here teachers may be less likely to talk about 'dealing with' parents but the question of whether these parents are true decision makers in their children's schooling still deserves scrutiny. What are the power arrangements at the base of this 'support'?

Some researchers draw clear distinctions between informing, involving, and engaging parents and community members in the life of the school (Amendt, 2008, pp. 2-3). Informing parents or guardians refers to unilateral communication from the school with regard to the events and activities of the school and any decisions deemed necessary to transmit. While sometimes used interchangeably in the literature, crucial differences between parent 'involvement' and 'engagement' lie with the type of relationship imagined and put into practice. Parents might be 'involved' with a school, but they are kept on the periphery and occupied with tasks that assist the teachers' and administrators' agenda in which they have had little or no voice. Parent engagement is characterized by "authentic partnership" in the "core work of teaching and learning” (Pushor, 2007b, pp. 5-6). Teachers and administrators recognize parent knowledge (Pushor et al., 2013; Pushor et al., 2015) and genuinely share decision-making power: "[w]ith parent engagement, possibilities are created for the structure of schooling to be flattened, power and authority to be shared by educators and parents, and the agenda being served to be mutually 
determined and mutually beneficial” (Pushor \& Ruitenberg, 2005, p. 13). Further Pushor (2007b) argues:

While it is important to engage parents on the school landscape, it is equally important for educators to move comfortably in the worlds of families and communities, off the school landscape. It is when these boundaries between school, home, and community become permeable and multidirectional that the creation of a shared world which supports and nurtures children is realized. (p. 6)

The extent to which there was a 'shared world' between educators and families in either of the schools in which David taught is questionable, but one school does seem to be more amenable to and appreciative of involving (if not engaging) parents. An area that would be interesting to explore with David and other teachers further is how parents, particularly those who live in poverty, may work to resist the sorting and labelling of their children into special needs categories which may be seen as further limiting their opportunities (see, for example, Holcomb-McCoy \& Bryan, 2010). The medical criteria for the assessment of ADHD, dependent as it is on qualitative measures of hyperactivity, impulsivity, and inattention (Biel \&McGee, 2011), may lead to medication of behavior that is a reflection of other issues and problems including socio-economic conditions and the regimens of school (Robinson, 2011).

What gender relations are masked by using gender neutral terms? If mothers are indeed more active in their children's schooling, then how might educators develop a more nuanced and critical understanding of this work and problematize the absence of fathers? David's recognition that he rarely interacts with dads around school-related concerns is consistent with the findings of Griffith's and Smith's (2005) sociological analysis. Their study makes visible the relationship of mothering work and schooling, showing how "mothering work contributes to the workings of the school system and is also organized by it” (p. 2). Using an institutional ethnographic approach to investigate the broader social relations or "ruling relations" (p.40) that organize everyday lives, they reveal the multi-faceted nature of unpaid mothering work which contributes to the educational work of schools and upon which schools depend to be considered successful: "Where such resources are plentiful in a given community, the school moves toward the educational ideal of an effective learning environment for all children” (p. $3)$. However, the capacity of mothers or fathers to contribute to the educational work of schools depends on a host of factors related to labour force participation and social class, and the limited time and resources of parents in some communities to do this unpaid work further fuels what Griffith and Smith call "an engine of inequality” in public education (p. 9). In those rural communities where farm work needs to be supplemented by waged labour in order to earn a living, the capacity of parents to be involved in children's schooling would be further limited.

Mothering work is amorphous and allencompassing involving the coordination of family schedules to align with school schedules, making sure students arrive at school on time, properly rested and well-nourished, in appropriate clothing, with prepared or arranged lunches and necessary materials, as well as having safe after-school supervision. Then there is the pedagogical work of providing children with activities at home or in the community to promote school readiness knowledge, age-appropriate skills, and personal development; oversight of their homework; and school-involvement activities such as fundraising or volunteering in the classroom. The institutional and discursive management of this taken-for-granted work is largely invisible, as is the work itself, except when it is not done, or done in a way that irritates teachers and administrators as appears to be the case in David's 58 school.

Griffith and Smith (2005) describe "the mothering discourse" as elaborated over the latenineteenth and twentieth century with the emergence of the middle class, and which positions professionals as the authorities on appropriate mothering and positions mothers as either good or bad in relation to the professionals' standards as diffused through texts, advice pamphlets, and other media (pp. 33-41). Educators have contributed to these nebulous yet inflexible standards of adequate parenting which assign disproportionate responsibility to mothers. Problems that children experience in school are more often viewed as stemming from the home or the children themselves rather than from practices within the school (Oakes, 2005, xvi). Griffith and Smith (2005) argue that " $[t]$ he mothering discourse makes no concessions to variations in the practical and material contexts of mothering work or to the 
realities of a mother's ability to control the school situation in which her child works during the day" (p.39).

As David notes, the mothers in the community of the 5-8 school not only did not have control over the daily routines and activities of the school, they had no control over the future existence of the school. The centrality of the school in the life of rural communities is well documented (see literature reviewed by Oncescu \& Giles, 2014, pp. 298-301). David's assessment that the decision about school closure was exacerbating tensions with parents in that community is reasonable. In addition to concern about their children's well-being and anticipation of difficulties commuting to and integration into a more distant school, the mothering work associated with this change could only intensify. The reaction of administrators and teachers was to withdraw and hunker down. While this reaction is understandable, it is not the most productive for the school learning environment. While David is cognizant of the higher level of poverty in this community, little is known about what accounts for the economic disparity between the two closely-situated communities. One wonders if an approach that focused on community strengths, revitalization, and resilience might have been more efficacious; however, it is easy to make judgements from outside the fray.

The study conducted by Martin, Dolmage, and Sharpe (2012) which includes veteran teachers indicates that "problems with parents" was the most common issue reported in teacher descriptions of their "worst experiences" (p.19). These researchers called for specific policies and procedures in schools to manage teacher-parent interactions including structuring interviews so that teachers are never alone in a room with a parent (p.19). Clearly, teacher parent relations are in need of fresh perspectives and deeper study than can be provided here; however, the material conditions of both teachers' and parents' work is an important starting place, and consideration as to how these conditions may vary in rural contexts is vital.

Griffith and Smith (2005) discuss what they refer to as the "new regime of accumulation" that occurred over the twenty-year course of their research during which the global movement of capital, free market policies, and communication technologies have dramatically restructured labor force participation towards high unemployment and/or casual, insecure work, as well as reduced state funding to public institutions (p. 128). Neoliberal economic policies have conjoined with neoconservative discourse to highlight individual and familial responsibility for social problems and to retreat from state intervention and collective responses. Educational reform, in tandem with reductions in funding, has shifted from a focus on equality to one of excellence and global competitiveness (Oakes, 2005, xvi). The impact on teachers' work is profound as high-stakes performance testing and other accountability measures direct teacher attention to teaching for the test. Drawing on the work of Gabbard (2008) and Hursh (2008), Costigan (2014) describes the current educational reform movement as "the ocean in which all educators and education researchers now swim, and it is generally agreed that this is a neoliberal, depersonalized, corporate-type of thinking applied to education, with all the apparatus of measuring, preoccupation with a numbers-based audit culture, and maintaining accountability through sanctions” (p.4). While the policies and practices associated with America's No Child Left Behind movement and its sequelae have not been taken up with the same intensity in Canadian provinces, in Saskatchewan "Lean management” programs are informing government priorities in the public sector (Kinsman et al, 2014; Moraros, Lemstra, \& Nwankwo 2016; PricewaterhouseCoopers, 2014) with attendant concern about the effects on workload and the professional autonomy of teachers in the case of K12 Education (Froese-Germain, 2004; Saskatoon Teachers Federation, 2014a). It is telling that studies that include long-term career teachers report similar challenges as beginning teachers with teachers' multiple roles, student needs and challenging behavior, heavy workloads, insufficient time, and issues with parents figuring prominently (Martin, Dolmage, \& Sharpe, 2012, 18-20; see also, Berry, Smylie, \& Fuller, 2008; Freiler, et al., 2012; Leithwood, 2006; Saskatoon Teachers’ Federation, 2014b).

\section{Conclusion}

What does all this mean for beginning teachers in rural contexts? David's experience is in many ways typical of the beginning teachers in this study: backdoor connection to employment, intense involvement, blurring of the professional and personal. His account of two schools as different as “day and night” helps us as researchers and 
professional supporters to focus more broadly on the institutional context and material conditions of teachers' work as well as parents' work, the boundaries of which have been redrawn and reshaped by neoliberal economic policies and the erosion of public funding. His story underscores the diverse contexts of rural schools in Saskatchewan as documented by Hellsten, McIntyre, and Prytula (2011), and directs researchers to consider different lines of inquiry in the search for explanations.

The discourse of school effectiveness that David draws on to make sense of the differences in his two schools may be as impervious to shifting social and material conditions as the discourse of mothering. A research approach such as institutional ethnography begins with people's experience in an institutional setting but moves to an investigation of their work as sequenced activities related to and coordinated by the work of a number of institutions in often invisible or taken-for-granted ways (Griffith \& Smith, 2005, pp.124-5). If we look beyond the experience of beginning teachers to how that experience is discursively and institutionally organized and dependent on the work of others such as parents (usually mothers), then we can develop a nuanced appreciation of the complexities of learning to teach attuned to variation in social class and local circumstances.

While the processes of teacher induction are important, research that takes up the larger social and economic forces organizing life within rural communities including teachers' work can yield differentiated perspectives that generate locallycalibrated recommendations. Such an approach is consistent with a focus "on the education and socialization of new teachers and their ecological understanding of where they live" (Costigan, 2014, p.3, emphasis in original). The recent special issue of Teacher Education Quarterly (2014) reaffirms the importance of "the personal, autobiographical, and ecological understandings of learning to teach" (Costigan, 2014, p. 6) as told through the stories of the people who are doing it. Their stories and the concepts incorporated in them are tested through "encountering the world" over the length of a career such that "the ongoing narrative of understanding is solidified, modified, or abandoned” (p.4). As David moves through his career, he will continue to work to make sense of the teaching and learning landscape and test his ideas through encounters with the world. As researchers, these renderings of experience become points of entry into examination of the social relations that organize and shape that world.

Research group: Laurie-Ann M. Hellsten, PI; Gwen Dueck; Bruce Karlenzig; Stephanie Martin; Dianne Miller; Janet McVittie; and Cecilia Reynolds. We acknowledge support of the Social Science and Humanities Research Council of Canada.

\section{References}

Amendt, T. (2008). Involvement to engagement: Community education practices in a suburban elementary school and an inner-city community school (Master's thesis, University of Saskatchewan, Canada). Retrieved from http://ecommons.usask.ca/handle/10388/etd03192008-140125

Angus, C. (2015). Children of the broken treaty: Canada's lost promise and one girl's dream. Regina, SK: University of Regina Press.

Ares Abalde, M. (2014). School size policies: A literature review. OECD Education Working Papers No. 106. Paris: Organization for Economic Cooperation and Development (OECD). doi: http://dx.doi.org/10.1787/5jxt472ddkjl-en Berry, B., Smylie, M., \& Fuller, E. (2008). Understanding teacher working conditions: A review and look to the future. Retrieved from the Center for Teaching Quality website: http://www.teachingquality.org/sites/default/file s/Understanding\%20Teacher\%20Working\%20 Conditions\%20A\%20Review\%20and\%20Look\%20to\%20 the\%20Future.pdf

Biel, M.G. \& McGee, M.E. (2011). Assessment of Attention-deficit Hyperactivity Disorder. Pediatric Annals, 40(10), 493-498.

Bollman, R.D., \& Clemenson, H.A. (2008). Structure and change in Canada's rural demography: An update to 2006. Rural and Small Town Canada Analysis Bulletin, 7(7). Catalogue no. 21-006$X$. Archived on Statistics Canada website: http://www.statcan.gc.ca/pub/21-006-x/21-006x2007007-eng.pdf 
Boyatzis, R.E. (1998). Transforming qualitative information: Thematic analysis and code development. Thousand Oaks, CA: Sage.

Braun, V., \& Clarke, V. (2006). Using thematic analysis in psychology. Qualitative Research in Psychology, 3(2), 77-101.

Corbett, M. (2007). Learning to leave: the irony of schooling in a coastal community. Black Point, NS: Fernwood.

Costigan, A. T. (2014). Ecological perspectives of learning to teach: Introduction to a special issue of Teacher Education Quarterly. Teacher Education Quarterly, 41(1), 3-8. Retrieved from

http://search.proquest.com/docview/176282728 1 ? accountid=14739

Creemers, B.P.M. \& Reezig, G.J. (1997). School effectiveness and school improvement: Sustaining links. School Effectiveness and School Improvement, 8(4), 396-429. doi: 10.1080/0924345970080402

Draper, S. (2000). Teaching from the heart: Reflections, encouragement, and inspiration. Portsmouth, NH: Heinemann.

Fantilli, R.D. \& McDougall, D.E. (2009). A study of novice teachers: Challenges and supports in the first years. Teaching and Teacher Education, 25, 814-825.

First Nations elementary and secondary schools. (n.d). Retrieved July 3, 2017, from Indigenous and Northern Affairs Canada (formerly Aboriginal Affairs and Northern Development Canada) website: https://www.aadncaandc.gc.ca/eng/1100100033676/11001000336 $\underline{77}$

Freiler, C., Hurley, S., Canuel, R., McGahey, B., Froese-Germain, B., \& Riel, R. (2012). Teaching the way we aspire to teach: Now and in the future. Toronto, ON: Canadian Education Association and Canadian Teachers Federation.

Froese-Germain, B. (2004). Educational accountability with a human face. Ottawa, ON: Canadian Teachers Federation.

Gourneau, B. (2014). Challenges in the first year of teaching: Lessons learned in an elementary education resident teacher program. Contemporary Issues in Education Research (Online), 7(4), 299-318. Retrieved from http://search.proquest.com/docview/161302707 $\underline{\text { 9? accountid }=14739}$
Griffith, A. \& Smith, D. (2005). Mothering for schooling. New York: Routledge.

Gruwell, E. (2007). Teach with your heart: Lessons learned from the Freedom Writers. New York: Broadway Books.

Hebert, E., \& Worthy, T. (2001). Does the first year of teaching have to be a bad one? A case study of success. Teaching and Teacher Education, 17, 897-911.

Hellsten, L., McIntyre, L. \& Prytula, M. (2011). Teaching in rural Saskatchewan: First year teachers identify challenges and make recommendations. Rural Educator, 32(3), 1121.

Holcomb-McCoy, C., \& Bryan, J. (2010). Advocacy and empowerment in parent consultation: Implications for theory and practice. Journal of Counseling and Development: JCD, 88(3), 259268. Retrieved from http://search.proquest.com/docview/519490148 ?accountid $=14739$

Intrator, S. (2002). Stories of the courage to teach: Honoring the teacher's heart. San Francisco, CA: Jossey-Bass.

Kinsman, L., Rotter, T., Stevenson, K., Bath, B., Goodridge, D., Harrison, L. ...\& Westhorp, G. (2014). "The largest Lean transformation in the world": The implementation and evaluation of Lean in Saskatchewan healthcare. Healthcare Quarterly, 17(2), 29-32.

Kirk, J. (2008). An examination of school division restructuring in Saskatchewan. Research report \#08-03. Regina, SK: Saskatchewan School Boards Association.

Leithwood, K. (2006). Teaching working conditions that matter: Evidence for change. Toronto, ON: Elementary Teachers Federation of Ontario.

MacDonald, D. (1999). Teacher attrition: A review of the literature. Teaching and Teacher Education 15(8), 835-848.

Martin, R.R., Dolmage, R., \& Sharpe, D. (2012). Seeking wellness: Descriptive findings from the survey of the worklife and health of teachers in Regina and Saskatoon. Saskatoon, SK: Saskatchewan Teachers' Federation. Retrieved from Saskatchewan Teachers' Federation website: https://www.stf.sk.ca/portal.jsp?Sy3uQUnbK9L 2RmSZs02CjV3Jh9YwRCfE6GxQHQpP6toQ= $\underline{F}$ 
Moraros, J., Lemstra, M., Nwankwo, C. (2016). Lean interventions in healthcare-do they actually work? A systematic literature review. International Journal for Quality in Healthcare, 150-165. doi: 10.1093/intqc/mzv123

Oakes, J. (2005). Keeping track: How schools structure inequality. $2^{\text {nd }}$ edition. New Haven, CT \& London, UK: Yale University Press.

Okhremtchouk, I.S., Jiménez, R.M., Rosa. R., Porter, S.G., Bhand, N., Cramer, M., Lang, G., Magill, K., Mathrole, R., \& Poulin, K. (2015). From student teachers to teachers of students: Beginning teachers' journeys from pre-service to the classroom. Creative Education, 6, 331337. http://dx.doi.org/10.4236/ce.2015.63031

Oncescu, J., \& Giles, A. (2014). Rebuilding a sense of community through reconnection: The impact of a rural school's closure on individuals without school-aged children. The Journal of Rural and Community Development, 9(3), 295318.

Palmer, P. (2007). The courage to teach: Exploring the inner landscape of a teacher's life. San Francisco, CA: Jossey-Bass.

PricewaterhouseCoopers. (2014). Education matters ( $5^{\text {th }}$ edition). Author. Retrieved from https://www.pwc.com/ca/en/public-sectorgovernment/publications/pwc-educationmatters-fifth-edition-2014-11-en.pdf

Pushor, D. (2007a). Welcoming parents: Educators as guest hosts on school landscapes. Education Canada, 47(4), 6-11.

Pushor, D. (2007b). Parent engagement: Creating a shared world. Invited research paper to the Ontario Education Research Symposium January 18-20. Retrieved from http://ecadmin.wdfiles.com/local--files/ecfe-201/Parent $\% 20$ Engagement $\% 20$ \%20Creating\%20a\%20Shared\%20World.pdf

Pushor, D. \& Parent engagement collaborative. (2013). Portals of promise: Transforming beliefs and practices through a curriculum of parents. Rotterdam, NL: Sense publishers.

Pushor, D. \& Parent engagement collaborative II (2015). Living as mapmakers: Charting a course with children guided by parent knowledge. Rotterdam, NL: Sense Publishers.

Pushor, D., Ruitenberg, C., with co-researchers from Princess Alexandra Community School. (November 2005). Parent engagement and leadership. Research report, project \#134.
Saskatoon, SK: Dr. Stirling McDowell Foundation for Research into Teaching.

Renihan, F.I., \& Renihan, P.J. (1989). School improvement: Second generation issues and strategies. In B.P.M. Creemers, T.A. Peters, \& D. Reynolds (Eds.), School effectiveness and school improvement (pp. 365-377). Amsterdam/Lisse: Swets \& Zeitlinger.

Renihan, P. \& Renihan, F. (July 1991). School effectiveness and smallness...The School Trustee, 20-23.

Robinson, K. (04/13/11). Changing education paradigms. RSA Animate. Retrieved from http://sirkenrobinson.com/watch/

Romano, M., \& Gibson, P. (2006). Beginning teacher successes and struggles: An elementary teacher's reflections on the first year of teaching. The Professional Educator, 2(1), 116. Retrieved from https://eric.ed.gov/?id=EJ773848\

Sackney, L., Walker, K., \& Hajnal, V. (1998). Leadership, organizational learning, and selected factors relating to the institutionalization of school improvement initiatives. Alberta Journal of Educational Research, 44(1), 70-81. Retrieved from http://search.proquest.com/docview/228616832 ?accountid=14739

Sask school divisions announce 14 closures. (May 08, 2007). Retrieved from Canadian Broadcasting Corporation website: http://www.cbc.ca/news/canada/saskatchewan/s ask-school-divisions-announce-14-closures1.655750

Saskatchewan Teachers Federation. (February, 2014a). Education Sector Planning: Submission to the Ministry. Saskatoon, SK: Author. Retrieved from STF website: https://www.stf.sk.ca/portal.jsp?Sy3uQUnbK9L 2RmSZs02CjV3Jh9YwRCfE6w9LXwT/TnxY= F

Saskatchewan Teachers Federation. (February, 2014b). Education Sector Planning: Teacher engagement with the Ministry of Education. Saskatoon, SK: Author. Retrieved from STF website:

https://www.stf.sk.ca/portal.jsp?Sy3uQUnbK9L 2RmSZs02CjV3Jh9YwRCfE6UJ/MJdEAOhA= F 
Smith, D. (1987). The everyday world as problematic: A feminist sociology. Toronto, ON: University of Toronto Press.

Smith, G. (2002). Learning to be where we are. Phi Delta Kappan, 83(8), 584-594.

Statistics Canada. (2011). Census Profile. Author. Retrieved from Statistics Canada website: http://www12.statcan.gc.ca/censusrecensement/2011/dp-pd/prof/searchrecherche/frm res.cfm?Lang $=E \& T A B I D=1 \& G$ $=1 \&$ Geo $1=$ PR \&Code $1=01 \& G e 02=0 \&$ Code $2=0$ \&SearchPR $=01 \&$ SearchType $=$ Begins $\&$ SearchT ext=Saskatchewan

Statistics Canada. (2015). Employment by major industry group. Author. Retrieved from Statistics Canada website:

http://www.statcan.gc.ca/tables-tableaux/sumsom/101/cst01/labr67i-eng.htm

Tremblay, J. (2001). Rural youth migration between 1971 and 1996. Working Paper \#44. Ottawa, ON: Statistics Canada. Archived on Government of Canada Website: http://www.publications.gc.ca/site/archivee- archived.html?url=http://www.publications.gc.c a/Collection/Statcan/21-601-MIE/21-601MIE2001044.pdf

Trujillo, T. (2013). The reincarnation of the effective schools research: Rethinking the literature on district effectiveness. Journal of Educational Administration, 51(4), 426-452. doi:http://dx.doi.org/10.1108/095782313113256 40

Van Zandt Allen, L. (2013). The impact of induction support on teacher development, teacher retention, and the teacher quality issue. Teacher Education Quarterly, 40(3), 75-92. Retrieved from http://www.jstor.org/stable/43684703

Wittman, H., Desmarais, A., \& Wiebe, N. (2011). Food sovereignty in Canada: Creating just and sustainable food systems. Winnipeg, MN: Fernwood.

Zepeda, S.J., \& Ponticell, J.A. (1997). First-year teachers at risk: A study of induction at three high schools. The High School Journal, 81(1), $8-21$.

\section{About the authors:}

Dianne M. Miller teaches and researches in land- and place-based pedagogies, rural revitalization, life history, and history of education. She was part of a research team investigating the experiences of beginning teachers in Saskatchewan.

Laurie-Ann M. Hellsten led the initial study of beginning teachers in Saskatchewan and has a diverse research program in instrument development, analysis, and validation; health and health promotion; teacher induction; and children's oral language and writing development. 